\title{
Effective cytotoxic activity of OSW-1 on colon cancer by inducing apoptosis in vitro and in vivo
}

\author{
YANHONG ZHANG $^{1 *}$, FENGQI FANG ${ }^{2 *}$, KAI FAN $^{3}$, YANLI ZHANG ${ }^{3}$, \\ JIE ZHANG $^{2}$, HUISHU GUO ${ }^{4}$, PEIYAO YU ${ }^{2}$ and JIANMEI MA ${ }^{3}$ \\ ${ }^{1}$ Graduate School of Dalian Medical University, Dalian, Liaoning 116044; ${ }^{2}$ The First Affiliated Hospital of \\ Dalian Medical University, Dalian, Liaoning 116011; ${ }^{3}$ Department of Anatomy, Dalian Medical University; \\ ${ }^{4}$ Centralab, The First Affiliated Hospital of Dalian Medical University, Dalian, Liaoning 116044, P.R. China
}

Received September 18, 2016; Accepted February 22, 2017

DOI: $10.3892 /$ or.2017.5582

\begin{abstract}
As a natural compound, Ornithogalum caudatum Ait is primarily used as an anti-inflammatory and antitumor agent in Chinese folk medicine. In 1992, OSW-1 was isolated from this compound, which is a new member of cholestane saponin family. In numerous recent studies, OSW-1 has been shown to have powerful cytotoxic anticancer effects against various malignant cells. However, the therapeutic efficacy of OSW-1 on colon cancer and the underlying mechanism are not understood. To explore the mechanism underlying OSW-1 in antitumor therapy, a therapeutic function analysis of OSW-1 on colon cancer was performed in vitro and in vivo. It was shown that with low toxicity on normal colonic cells, OSW-1 suppresses colon cancer cells in vitro and this inhibition was via the intrinsic apoptotic pathway, which increased cellular calcium, changed mitochondrial membrane potential, disrupted mitochondrial morphology, and led to the release of cytochrome $\mathrm{c}$ and the activation of caspase-3. Furthermore, in a nude mouse model, OSW-1 had a powerful effect on suppressing colon tumor proliferation without significant side effects through the apoptosis pathway. Taken together, these results demonstrate that OSW-1 is a potential drug for colon cancer treatment.
\end{abstract}

Correspondence to: Professor Peiyao Yu, The First Affiliated Hospital of Dalian Medical University, 193 Joint Road, Dalian, Liaoning 116000, P.R. China

E-mail: ypy0411@sina.com

Professor Jianmei Ma, Department of Anatomy, Dalian Medical University,9 West Section Lvshun South Road,Dalian, Liaoning 116044, P.R. China

E-mail:ma_jianmei@hotmail.com

${ }^{*}$ Contributed equally

Key words: Ornithogalum caudatum Ait, OSW-1, apoptosismitochondria, colon cancer

\section{Introduction}

Colon cancer is one of the most common causes of cancer deaths worldwide (1). Despite the current use of several efficient chemotherapeutic drugs, such as oxaliplatin, irinotecan, and fluorouracil, mounting evidence has shown that most treatments are not sufficiently effective due to toxicity and the development of drug resistance. The discovery of therapeutic agents with reduced toxicity and the capacity to decrease drug resistance is a challenging task for the treatment of colon carcinoma.

Currently, natural compounds are being increasingly used in anticancer strategies as potential drugs. Taxol, now used to treat millions of patients worldwide with ovarian, breast, and lung cancers, is isolated from the plant, Taxus brevifolia (2). Because of their minimal adverse and powerful anticancer effects, natural products have intrigued a growing number of experimental biologists and clinicians engaged in developing new anticancer drugs.

Ornithogalum caudatum Ait (OCA) was originally classified in the family Liliaceae. In Chinese folk medicine, OCA is known to have anti-inflammatory and antitumor properties. OCA has also been used in therapy for hepatitis and some types of cancers. Most uses of OCA in folkloric medicine lack theoretical guidance, and some uses are even poisonous. In 1992, Kubo et al (3) isolated a steroidal glycoside, OSW-1, from OCA bulbs. The steroidal glycosides from Ornithogalum plants can be classified into four groups (cardenolide, cholestane, spirostane, and stigmastane glycosides (4). OSW-1 is classified as cholestane glycoside chemical structure formula: $[3 \beta, 16 \beta, 17 \alpha$-trihydroxycholest-5-en-22-one16-O-(2-O-4methoxybenzoyl- $\beta$-D-xylopyranosyl)-( $1 \rightarrow 3)-(2-\mathrm{O}$-acetyl- $\alpha$-Larabinopyranoside)]. Several studies have suggested that OSW-1 has a potent anti-proliferative effect against a variety of tumor cell lines, such as leukemia, pancreatic cancer, malignant brain tumor, and hepatocellular carcinoma cells, but is less toxic to non-malignant cells in vitro $(5,6)$; however, it is so difficult to isolate the compound in certain stages that the application is restricted to research. Recent studies have shown that the synthesis of OSW-1 and its derivatives has gradually improved; however, this finding provides the premise for a possible therapeutic application for OSW-1 in the future (7-24). We determined whether the anti-proliferative effect of OSW-1, 
the mechanism of which is not completely understood, can be extrapolated to colon cancer cells. This is the first study to describe OSW-1 as a potent cytotoxic agent in colon carcinoma in vitro and in vivo.

\section{Materials and methods}

Cell lines and chemicals. The colon cancer cell lines, LoVo and SW480 cells, were obtained from the Obio Technology (Shanghai, China). LoVo cells were cultured in DMEM (Gibco, Grand Island, NY, USA) containing 10\% FBS (Gibco) and 1\% streptomycin/penicillin in $5 \% \mathrm{CO}_{2}$ at $37^{\circ} \mathrm{C}$. SW480 cells were maintained in RPMI-1640 (Gibco) supplemented with $10 \%$ FBS and $1 \%$ streptomycin/penicillin at $37^{\circ} \mathrm{C}$ in $5 \% \mathrm{CO}_{2}$. OSW-1 [3 $\beta, 16 \beta, 17 \alpha$-trihydroxycholest-5-en-22-one16-O(2-O-4-methoxybenzoyl- $\beta$-D-xylopyranosyl)-(1-3)-(2-O-acetyl$\alpha$-L-arabinopyranoside)] was obtained from Changbai Mountain Institute of Traditional Chinese Medicine (Changbai, China). OSW-1 was extracted with ethyl alcohol at $70^{\circ} \mathrm{C}$ for $3 \mathrm{~h}$. The filtrate was extracted with water several times. Then, the filtrate was concentrated to a relative density of 1.10 . The extracts included the following: OSW-1, 0.45\%; alkaloids, $0.6 \%$; flavone, $0.15 \%$; and polysaccharide, $68 \%$. The mixture was extracted by ether, then the ether layer was discarded and the water layer was extracted with chloroform. This product has obtained national patents in China (CN 1,352,986, CN 1,354,011, and CN 1,672,728) (25-27). OSW-1 was analyzed using reverse-phase HPLC with electrospray ionization and atmospheric pressure chemical ionization quadrupole MS.

Cellular proliferation. To observe the effect of OSW-1 on cell viability, LoVo and SW480 cells were seeded in 96-well plates at a concentration of $1 \times 10^{5}$ cells/well. Following overnight incubation, the cells were treated with several concentrations of OSW-1 and incubated at $37^{\circ} \mathrm{C}$ in $5 \% \mathrm{CO}_{2}$ for 24,48 , and $72 \mathrm{~h}$. Cell viability analysis was determined using a Cell Counting Kit-8 Assay (CCK8; Dojindo, Tokyo, Japan). Each assay was performed in quintuplicate and repeated three times.

TUNEL assay. An In Situ Cell Death Detection kit was used to perform TdT-mediated dUTP nick end-labeling (TUNEL; Roche Diagnostics, Indianapolis, IN, USA) to evaluate apoptosis. Specifically, LoVo cells were seeded on coverslips at a concentration of $1 \times 10^{5}$ cells. Following an overnight incubation, the cells were treated with $180 \mathrm{ng} / \mathrm{ml}$ of OSW-1. After a 24-h incubation at $37^{\circ} \mathrm{C}$ in $5 \% \mathrm{CO}_{2}$, the adherent cells were fixed with $4 \%$ paraformaldehyde in PBS ( $\mathrm{pH} \mathrm{7.4)} \mathrm{for} 1 \mathrm{~h}$ at $4^{\circ} \mathrm{C}$, washed in PBS, then incubated in permeabilization solution $(0.1 \%$ Triton $\mathrm{X}-100$ ) for $2 \mathrm{~min}$ at $4^{\circ} \mathrm{C}$. The cells were then incubated in the TUNEL reaction mixture (according to the manufacturer's recommendations) for $1 \mathrm{~h}$ at $37^{\circ} \mathrm{C}$ in the dark, washed in PBS three times, and incubated in DAPI staining for $20 \mathrm{~min}$ at room temperature. The number of apoptotic cells were counted using an Olympus IX70 inverted fluorescence microscope. The cells were scored in 8 randomly chosen fields under a magnification of 400x per coverslip on at least 2 coverslips per treatment.

Flow cytometry analysis. For the apoptosis assay, LoVo cells $\left(1 \times 10^{6}\right)$ were treated with 90 and $180 \mathrm{ng} / \mathrm{ml}$ of OSW-1 for $24 \mathrm{~h}$. Then, the cells were collected and washed with cold PBS and resuspended in $100 \mu \mathrm{l}$ of binding buffer. Finally, $5 \mu \mathrm{l}$ of Annexin V-FITC and $5 \mu \mathrm{l}$ of propidium iodide staining solution were added for $15 \mathrm{~min}$ in the dark. The apoptosis rate was measured by flow cytometry (BD Biosciences, San Diego, CA, USA). To measure cytosolic calcium levels, LoVo cells were treated with $180 \mathrm{ng} / \mathrm{ml}$ of OSW-1 for 2, 4, 6, and $8 \mathrm{~h}$. Then, the cells were incubated with $5 \mu \mathrm{M}$ Calcium Green $^{\mathrm{TM}}-1 \mathrm{AM}$ (Invitrogen, Eugene, OR, USA) for $1 \mathrm{~h}$ at room temperature. The cells were washed with cold PBS, and then analyzed by flow cytometry. To measure active caspase- 3 , LoVo cells were treated with $180 \mathrm{ng} / \mathrm{ml}$ of OSW-1 for $12 \mathrm{~h}$, incubated with primary antibodies (anti-cleaved-caspase-3, 1:500 dilution; Cell Signaling Technology, Danvers, MA, USA), followed by horseradish peroxidase-conjugated secondary antibody (Santa Cruz Biotechnology, Inc., Santa Cruz, CA, USA), and analyzed by flow cytometry.

Isolation of mitochondria. Mitochondria were isolated with a mitochondria extraction kit (Beyotime Biotechnology, Shanghai, China) according to the manufacturer's protocol. Briefly, two groups of LoVo cells were harvested and washed with cold PBS, resuspended with extraction buffer, and incubated on ice for $15 \mathrm{~min}$. The cells were homogenized in a glass homogenizer and centrifuged at $1000 \mathrm{x} \mathrm{g}$ for $10 \mathrm{~min}$ at $4^{\circ} \mathrm{C}$, then the supernatant was transferred to a new centrifuge tube and centrifuged at $3500 \mathrm{x}$ g for $10 \mathrm{~min}$. At this stage, the precipitate was collected and resuspended with mitochondrial lysis buffer and labeled as mitochondria. At the same time, the supernatant was collected and centrifuged at $12000 \mathrm{x} \mathrm{g}$ for $10 \mathrm{~min}$. The resulting supernatant was designated as the cytosol. Both the mitochondria and cytosol were used to determine the release of cytochrome $\mathrm{c}$ by western blotting.

Western blot analysis. The mitochondrial and cytosol proteins isolated from LoVocells were subjected to SDS-polyacrylamide gel electrophoresis. Equal amounts of protein were loaded into each lane, separated in 15\% NuPAGE BT gels, transferred to PVDF membranes (Millipore, Billerica, MA, USA), and probed with primary antibodies (anti-cytochrome c, 1:1000 dilution; Santa Cruz Biotechnology, Inc.), followed by horseradish peroxidase-conjugated secondary antibody (Santa Cruz Biotechnology, Inc.).

Heterotopic xenograft tumor model. Four-week-old male nude mice were obtained from the Animal Experiment Center of Dalian Medical University. Animals were acclimatized to the animal housing facility for a period of 7 days before the beginning of the experiments. This study was approved by the Institution Animals Care and Use Committee. LoVo human colon cancer cells $\left(5 \times 10^{6}\right.$ cells in $\left.100 \mu \mathrm{l}\right)$ were injected subcutaneously into the right flank of 18 nude mice. When the tumor became palpable, the nude mice were randomized into two groups: i) intraperitoneal injection of PBS $(500 \mu \mathrm{l})$ daily in 9 nude mice; and ii) intraperitoneal injection of OSW-1 $(0.01 \mathrm{mg} / \mathrm{kg}$ diluted in PBS in $500 \mu \mathrm{l})$ daily in 9 nude mice (28). The body weights of the animals and tumor size were recorded every day, and the tumor volume was calculated [(length)x(width)x(length+width/2)x0.526=volume] (29). After 21 days of treatment, the animals were sacrificed and the tumors were excised and weighed. 
A
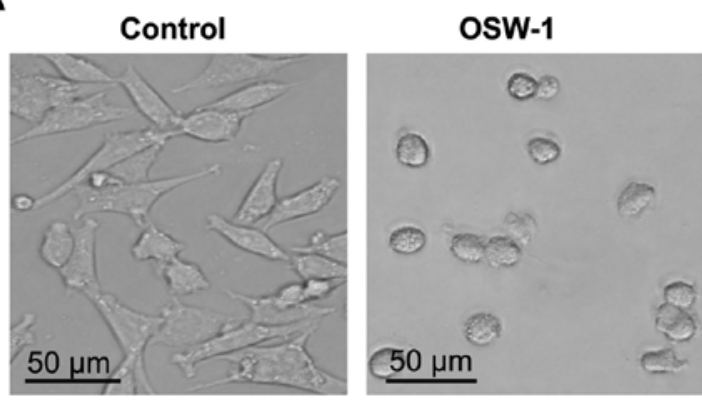

C

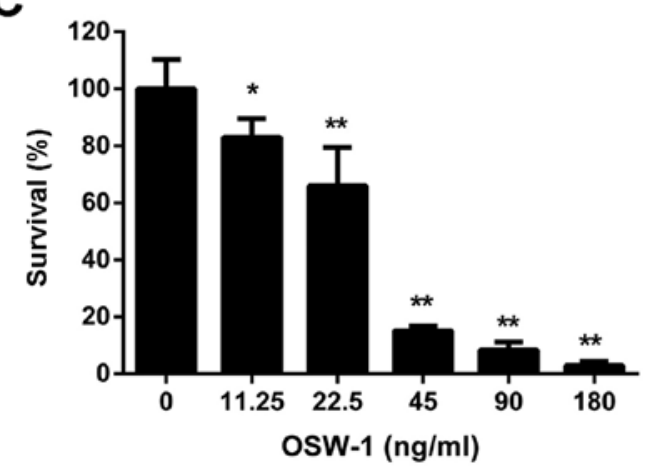

B

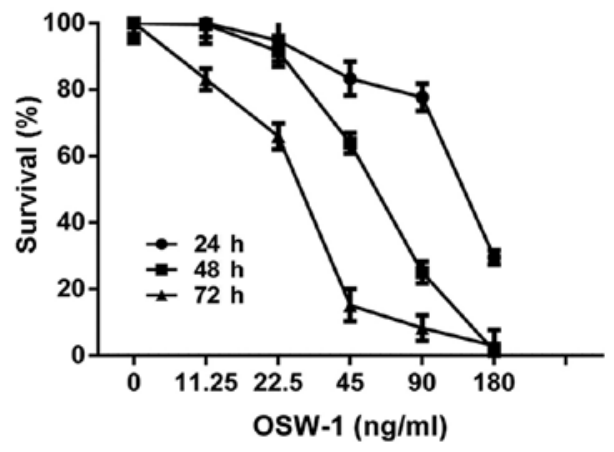

D

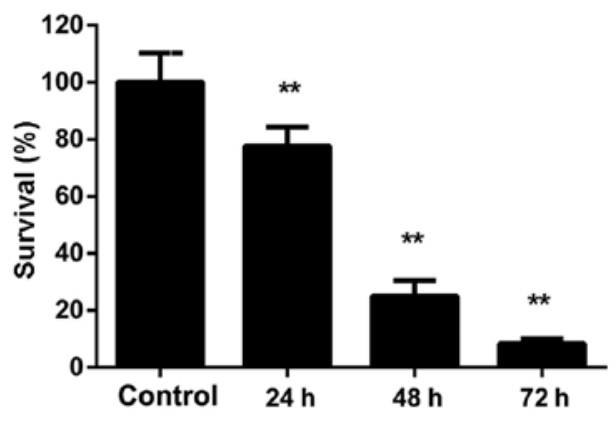

Figure 1. OSW-1 causes LoVo cell death in a dose- and time-dependent manner. (A) LoVo cells were observed under the optical microscope after treatment with $180 \mathrm{ng} / \mathrm{ml} \mathrm{OSW}-1$ for $12 \mathrm{~h}$. (B) LoVo cell viability was determined by CCK 8 assay after treatment with various concentrations of OSW-1 for 24,48 and $72 \mathrm{~h}$, respectively (C) LoVo cell viability was determined by CCK8 assay after treatment with various concentrations of OSW-1 for $72 \mathrm{~h}$, respectively. (D) LoVo cell viability was determined by CCK8 assay after treatment with $90 \mathrm{ng} / \mathrm{ml} \mathrm{OSW-1}$ for 24,48 and $72 \mathrm{~h}$, respectively. ${ }^{*} \mathrm{P}<0.05 ;{ }^{* *} \mathrm{P}<0.01$, compared with control. Scale bar, $50 \mu \mathrm{m}$ in (A).

Histology and immunohistochemistry. The tumors were cut, fixed for $24 \mathrm{~h}$ in $4 \%$ paraformaldehyde, and embedded in paraffin. The paraffin blocks underwent hematoxylin and eosin (H\&E) and immunohistochemical staining. For immunohistochemistry, the slides were boiled in $10 \mathrm{mM}$ sodium citrate buffer ( $\mathrm{pH}$ 6.0), maintained at a sub-boiling temperature for $40 \mathrm{~min}$, and cooled on the bench top for $2 \mathrm{~h}$. Then, the sections were incubated in $0.3 \%$ hydrogen peroxide for $15 \mathrm{~min}$ and each section was blocked with $200 \mu$ of blocking solution for $15 \mathrm{~min}$. Slides were incubated overnight at $4^{\circ} \mathrm{C}$ with $\mathrm{Ki} 67$ primary antibody (1:200 dilution; Cell Signaling Technology). After washing, the slides were incubated with pre-diluted biotinylated anti-rat IgG for $1 \mathrm{~h}$. The sections were then incubated with streptavidin horseradish-peroxidase. The immunoreactive cells were visualized with DAB chromogen.

Statistical analysis. The data in this study are presented as means \pm SD from a minimum of three independent experiments. Statistical analysis was performed using one-way ANOVA or by Student's t-test. A value of $\mathrm{P}<0.05$ was considered to indicate a statistically significant difference.

\section{Results}

OSW-1 has a cytotoxic effect on colon carcinoma cells, but not on normal cells. OSW-1 is more potent than clinical anticancer agents. We characterized the anti-proliferative effects of OSW-1 on SW480 and LoVo colon carcinoma cells by measuring cell viability using the CCK8 assay, and compared the results with other clinical anticancer agents. SW480 and LoVo cell lines are derived from a Dukes' stage B colon carcinoma and a colon carcinoma metastatic nodule, which represent non-metastatic and metastatic carcinomas, respectively $(30,31)$. As shown in Table I, OSW-1 exhibits not only extremely strong anticancer activity in SW480 and LoVo cell lines with an $\mathrm{IC}_{50}$ (half maximal inhibitory concentration) nanomolar concentration, but is also more potent than other anticancer agents by 10-100 times, with a lower cytotoxic effect on normal epithelial cells. These results indicate that OSW-1 has a powerful anticancer effect, but lower cytotoxic effect on normal cells. Since the LoVo cell line showed more sensitivity to OSW-1 when compared with SW480, we selected the LoVo cell line for further study.

We addressed in further detail the cytotoxic activity of OSW-1 on LoVo cells by both cell morphologic observations and the CCK8 assay. After treatment with OSW-1, LoVo cells shrank, were round in shape, and arranged loosely in monolayers. Most cells floated in the nutrient medium (Fig. 1A). The CCK8 assay shows that the proliferative rate decreased in a dose- and time-dependent manner after treatment with OSW-1 (Fig. 1B-D). Overall, these results show that OSW-1 has a cytotoxic effect on colon carcinoma cells, but not on normal cells, and is more potent than other anticancer agents used clinically.

Apoptosis is the main cause of LoVo cell death after exposure to $O S W-1$. A number of studies have demonstrated that the apoptotic pathway is the most important mechanism 
A

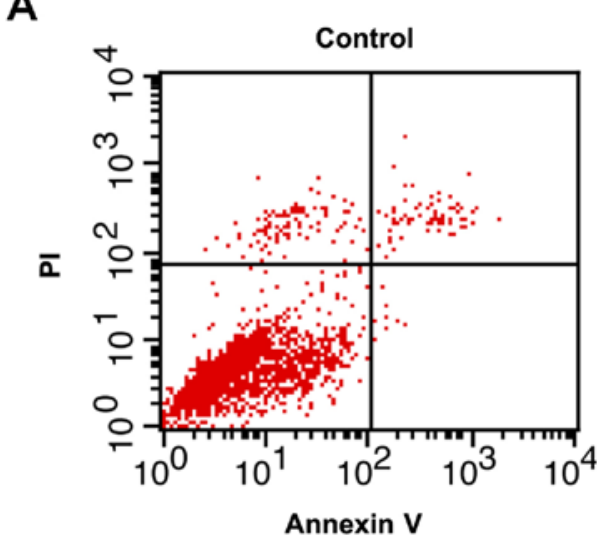

C

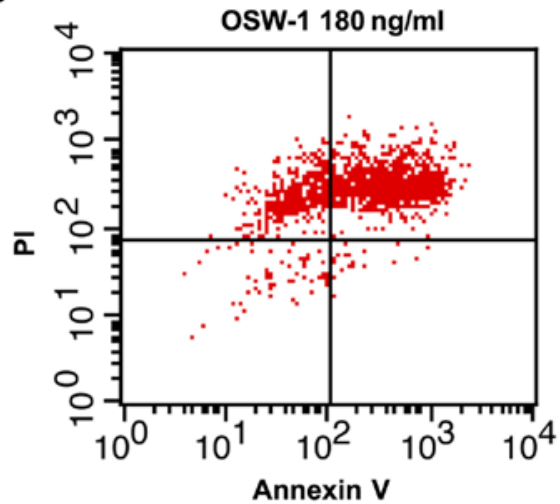

B

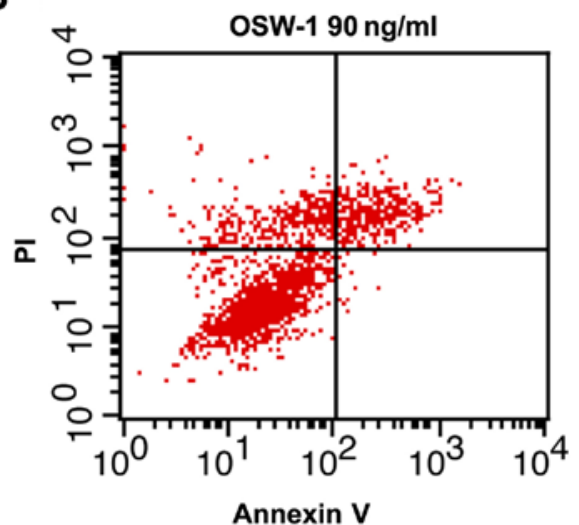

D

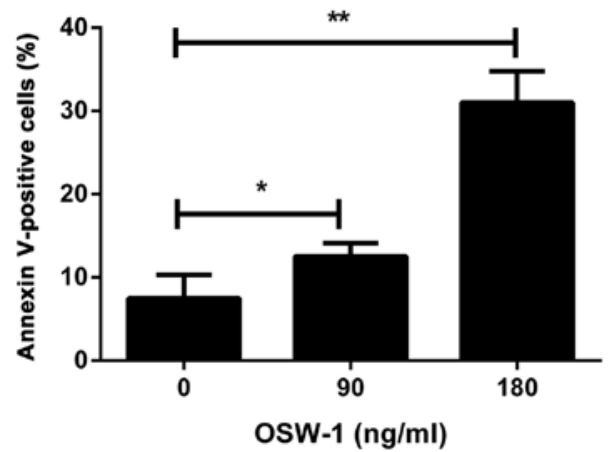

E
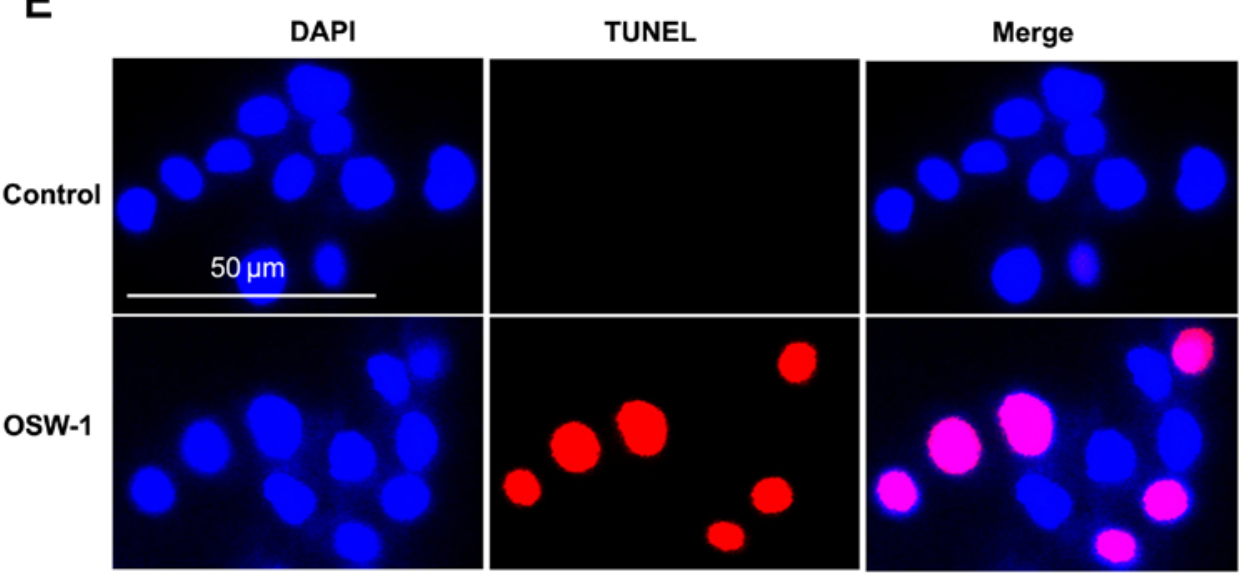

Figure 2. OSW-1 induces apoptosis of LoVo cells. (A-C) LoVo cells were seeded at a concentration of $1 \times 10^{6} \mathrm{cells} / \mathrm{ml}$, and treated with $90 \mathrm{ng} / \mathrm{ml}$ and $180 \mathrm{ng} / \mathrm{ml}$ OSW-1, respectively. Apoptosis of cells was quantified by flow cytometric analysis in which Annexin V-FITC and propidium iodide staining were used. (D) The percents of Annexin V-positive cells after OSW-1 treatment are shown in the bar graph in three independent Annexin V/PI stainings. (E) LoVo cells treated with $180 \mathrm{ng} / \mathrm{ml}$ OSW-1 for $24 \mathrm{~h}$ were observed with TUNEL staining (red). Cell nuclei were stained with DAPI (blue). ${ }^{*} \mathrm{P}<0.05 ;{ }^{* *} \mathrm{P}<0.01$, compared with control. Scale bar, $10 \mu \mathrm{m}$ in (E).

involved in the process of killing malignant cells with anticarcinogens $(32,33)$. Several studies have also shown that OSW-1 can induce calcium- or caspase-8-dependent cleavage of Bcl-2-mediated apoptosis $(34,35)$. Based on this study, we speculated that OSW-1 is capable of inducing apoptosis in LoVo cells. To verify this hypothesis, an Annexin V apoptosis assay was carried out using flow cytometry. After LoVo cells were exposed to 90 and $180 \mathrm{ng} / \mathrm{ml}$ of OSW-1 for $24 \mathrm{~h}$, approximately 19.85 and $84.20 \%$ cells lost viability, respectively, which was far more than untreated cells (Fig. 2A-C). In addi- tion, the percentages of apoptotic cells in both OSW-1 groups were significantly higher (Fig. 2D). These results indicate that OSW-1-induced anticancer activity might be mediated through the apoptotic pathway. Necrotic cells were also detected in the $180 \mathrm{ng} / \mathrm{ml} \mathrm{OSW-1-treated} \mathrm{group,} \mathrm{suggesting} \mathrm{that} \mathrm{there} \mathrm{may} \mathrm{be}$ other mechanisms involved than apoptosis. We further used a TUNEL assay to detect apoptosis morphologically. The results showed that apoptotic cells were mainly detected in LoVo cells after treatment with $180 \mathrm{ng} / \mathrm{ml}$ of OSW-1 for $24 \mathrm{~h}$, but rarely in untreated cells (Fig. 2E). 
A
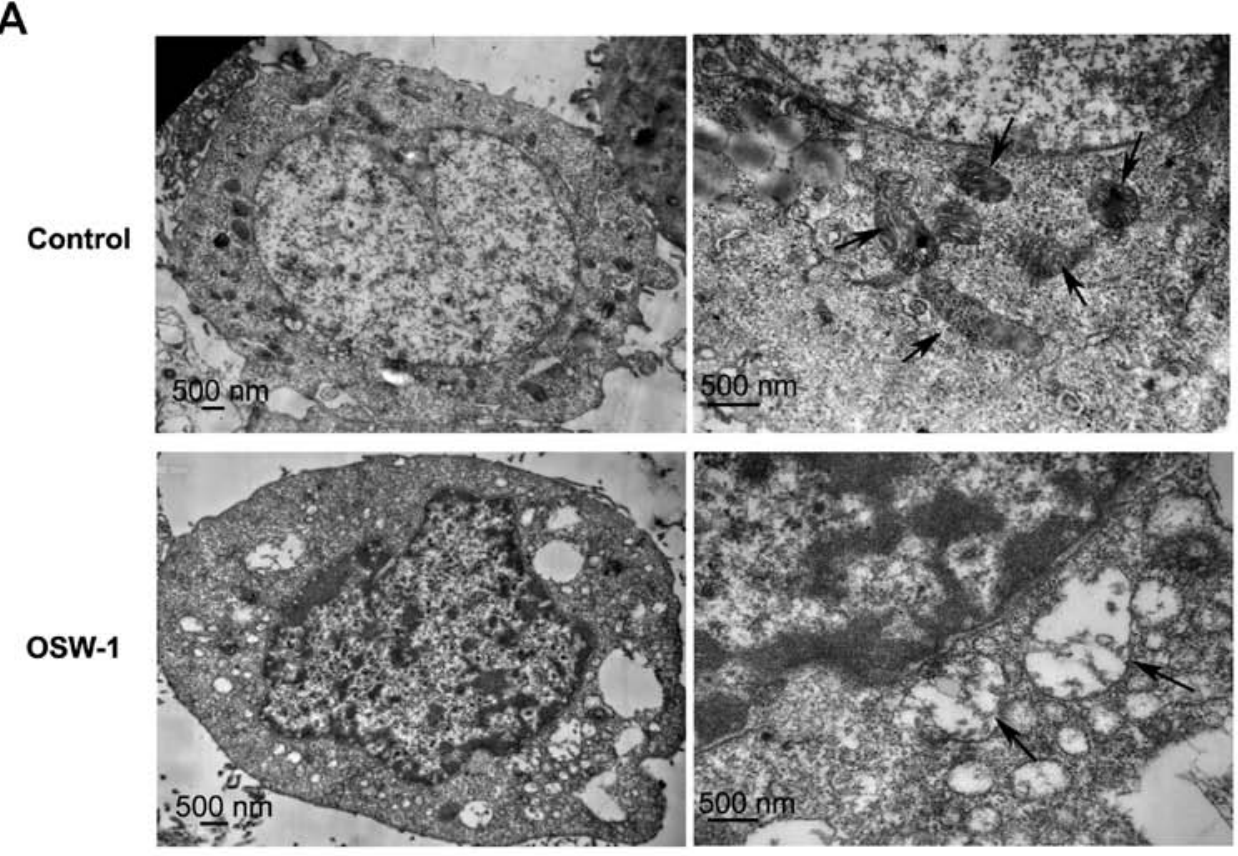

B

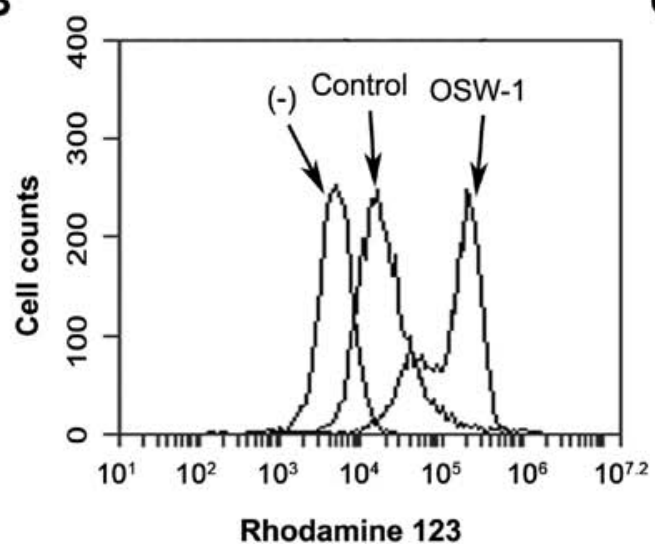

C

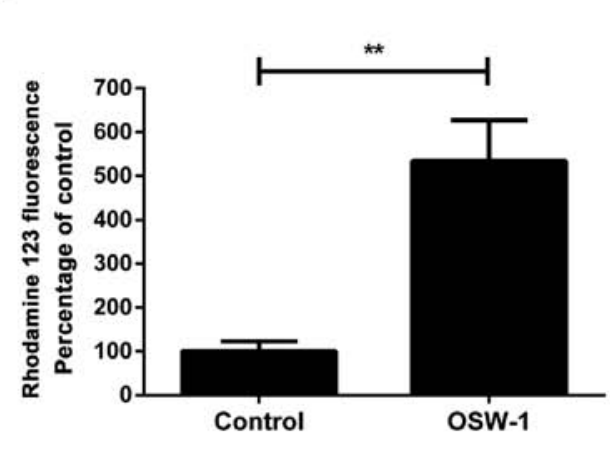

D

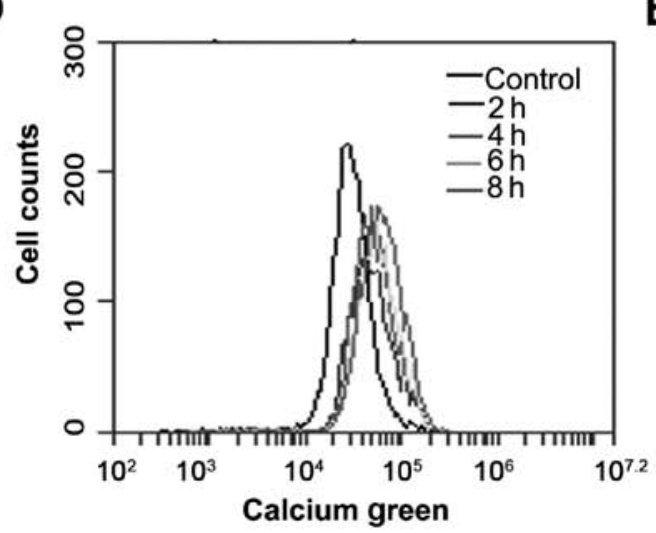

E

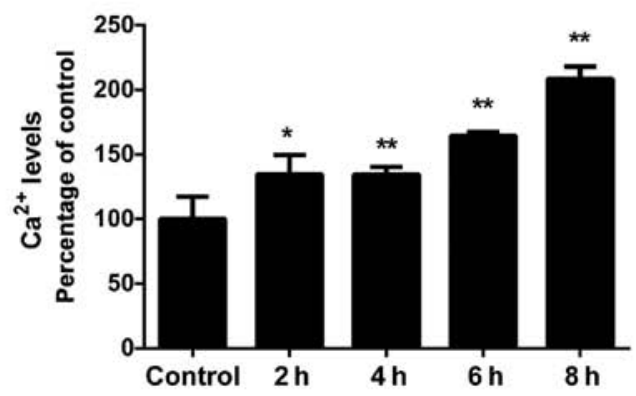

Figure 3. OSW-1-induced cell apoptosis is mediated by mitochondria injury. (A) LoVo cells untreated (upper panel) or treated (lower panel) with $180 \mathrm{ng} / \mathrm{ml}$ OSW-1 for $18 \mathrm{~h}$ were observed under the transmission electron microscopy. Mitochondria are shown by arrow heads. (B) LoVo cells were treated with $180 \mathrm{ng} / \mathrm{ml} \mathrm{OSW}-1$ for $12 \mathrm{~h}$ and stained by rhodamine 123, subsequently flow cytometry fluorescence analysis was used. (C) Quantitative analysis of the rhodamine 123 fluorescence intensity. (D) LoVo cells were treated with $180 \mathrm{ng} / \mathrm{ml} \mathrm{OSW}-1$ for $6 \mathrm{~h}$, and the cytosolic calcium changes were detected by Calcium Green staining and determined by flow cytometric analysis. (E) Quantitative analysis of Calcium Green fluorescence intensity at different time points. " $\mathrm{P}<0.05$; ${ }^{* *} \mathrm{P}<0.01$, compared with control. Scale bar, $500 \mathrm{~nm}$ in (A).

OSW-1-induces apoptosis was mediated by mitochondrial injury. To further explore the mechanism of apoptosis induced by OSW-1, we used transmission electron microscopy to investigate the ultrastructural changes in untreated and OSW-1-treated LoVo cells (Fig. 3A). Compared with untreated cells (Fig. 3A upper panel), substantial changes existed in the 
Table I. $\mathrm{IC}_{50}$ values of different antitumor drugs in colon cancer cells and normal epithelial cells.

\begin{tabular}{llll}
\hline & & \multicolumn{1}{c}{$\mathrm{IC}_{50}$} \\
\cline { 2 - 4 } Drug & \multicolumn{1}{c}{ LoVo } & \multicolumn{1}{c}{ SW480 } & Normal epithelial cells \\
\hline OSW-1 & $(3.1 \pm 0.2) \times 10^{-5}$ & $(6.1 \pm 0.1) \times 10^{-5}$ & $(13.9 \pm 0.9) \times 10^{-5}$ \\
Cisplatinum & $(17.2 \pm 5.2) \times 10^{-3}$ & $(13.4 \pm 2.2) \times 10^{-3}$ & $(1.5 \pm 0.3) \times 10^{-3}$ \\
5-Fluorouracil & $(214.4 \pm 36.7) \times 10^{-3}$ & $(299.7 \pm 79.2) \times 10^{-3}$ & $(56.8 \pm 78.9) \times 10^{-3}$ \\
Irinotecan & $(167.3 \pm 14.0) \times 10^{-3}$ & $(139.1 \pm 10.1) \times 10^{-3}$ & $(10.0 \pm 0.6) \times 10^{-3}$ \\
Gemcitabine & $(82.5 \pm 63.8) \times 10^{-3}$ & $(55.3 \pm 43.2) \times 10^{-3}$ & $\mathrm{ND}$ \\
\hline
\end{tabular}

Colon cancer cell lines LoVo cells and SW480 cells, and human normal colonic mucosal epithelial cells were treated with OSW-1 and Chemotherapeutic drugs used in clinic for $72 \mathrm{~h}$ at $37^{\circ} \mathrm{C}$. The $\mathrm{IC}_{50}$ values defined as the concentrations that cause a $50 \%$ loss of cell viability were determined by CCK8 Assay. Data were expressed as mean \pm SEM from three independent experiments.

cellular and mitochondrial morphology of OSW-1-treated cells, including concentrated and shrunken nucleus, lost cellular processes (Fig. 3A lower panel left), swollen mitochondria, and disrupted cristae (Fig. 3A arrow heads in lower panel). These ultrastructural changes are indicators of apoptosis mediated by mitochondrial injury, leading us to believe this mechanism was induced in OSW-1-treated cells. Next, we analyzed the function of mitochondria by flow cytometry analysis using the membrane potential fluorescent dye, rhodamine 123, which is readily sequestered by active mitochondria without a cytotoxic effect. The fluorescence intensity increased $>5$ times in OSW-1-treated cells (Fig. 3B), indicating mitochondrial injury.

Mitochondria maintain cytosolic calcium, which plays a key role in the regulation of cell death (36). Once mitochondria are damaged, intracellular calcium homeostasis is lost, leading to an increase in intracellular calcium. We determined the concentration of intracellular calcium ions by flow cytometry analysis using Calcium Green-1, an indicator of cell permeation by calcium, after LoVo cells were treated with $180 \mathrm{ng} / \mathrm{ml}$ of OSW-1 for 2, 4, 6, and $8 \mathrm{~h}$. The concentration of intracellular calcium ions gradually increased in proportion to the duration of OSW-1 treatment (Fig. 3D and E). These results suggest that OSW-1-induced apoptosis could be mediated by mitochondrial injury. Mitochondria can transiently store calcium, a contributing process for the cell homeostasis of calcium. Mitochondria injury can lead to abnormal increase of intracellular calcium concentration which is a critical event for cell death (36). We determined the concentration of intracellular calcium ions by flow cytometry analysis using Calcium Green-1, a fluorescence labeled calcium indicator, after LoVo cells were treated with $180 \mathrm{ng} / \mathrm{ml}$ of OSW-1 for 2, 4, 6, and $8 \mathrm{~h}$. We found that the concentration of intracellular calcium ions gradually increased in proportion to the duration of OSW-1 treatment (Fig. 3D and E) suggesting OSW-1-induced apoptosis could be mediated by mitochondrial injury.

OSW-1 induces apoptosis via the mitochondrial pathway. It is well-known that the mitochondrial pathway is a common way to mediate apoptosis (37). Based on the above results, we observed that OSW-1-induced apoptosis is likely to be mediated by mitochondrial damage, thus we focused on the molecules that may be involved in the mitochondrial apoptosis pathway. Since cytochrome c leakage from the mitochondria to the cytoplasm is an important event in the mitochondrial apoptotic pathway (38), we examined the protein content of cytochrome $\mathrm{c}$ in the mitochondria and cytoplasm from our cell lines by western blotting. Relatively higher cytochrome c levels were detected in the cytoplasm of OSW-1-treated cells (Fig. 4A and B). Furthermore, based on flow cytometry analysis, a nearly double level of protein content of cleaved caspase-3 was demonstrated in OSW-1-treated cells (Fig. 4C and D). Combined with the presence of apoptosome-specific cytochrome $\mathrm{c}$ this finding further supports the hypothesis that OSW-1 may induce mitochondrial pathway-mediated apoptosis (Fig. 4E).

The powerful effect of OSW-1 on suppressing colon tumors is without significant side effects in vivo. Overall, we observed that OSW-1 has a strong inhibitory effect on colon carcinoma cells with low cytotoxicity on normal cells. The main mechanism underlying this specific cytotoxic effect is apoptosis mediated by damaged mitochondria, which initiates the mitochondrial pathway of apoptosis (Fig. 4E). To ascertain whether or not OSW-1 was as effective in vivo, we adopted a nude mouse model inoculated by LoVo cells, in which OSW-1 treatment was performed when tumors became palpable. The results showed that the size of tumors in treated mice was smaller on average than control mice (Fig. 5A). The significant difference was observed from the 15-17th day following treatment, and this difference was gradually increased until the animals were sacrificed (Fig. 5B). Compared with the control group, the tumor weight of the OSW-1-treated group significantly decreased $(\mathrm{P}<0.05$; Fig. 5C and $\mathrm{D})$. Additionally, no apparent side effects were observed in OSW-1-treated mice. These results demonstrate that OSW-1 has powerful effects on suppressing colon tumor growth without significant side effects in vivo.

Inhibitory effect of OSW-1 on colon cancer proliferation is exerted through the apoptosis pathway. To evaluate the pathologic characteristics of tumors, tumor tissue sections were performed for H\&E and IHC staining using Ki67 antibody (1:200 antibody; Cell Signaling Technology), which is a marker of cell proliferation. Using H\&E staining, we found a 
A

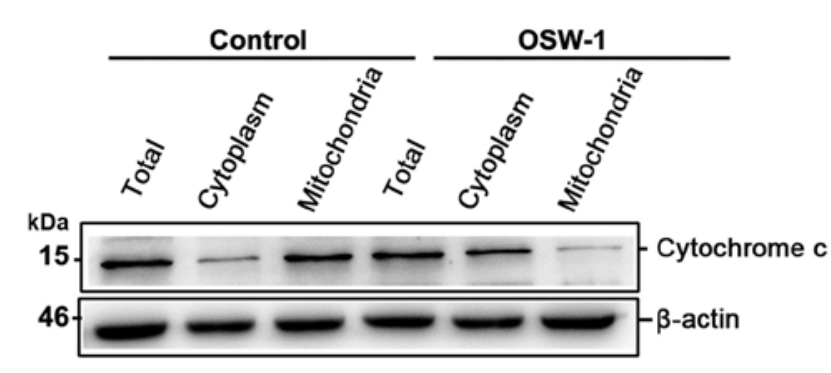

C

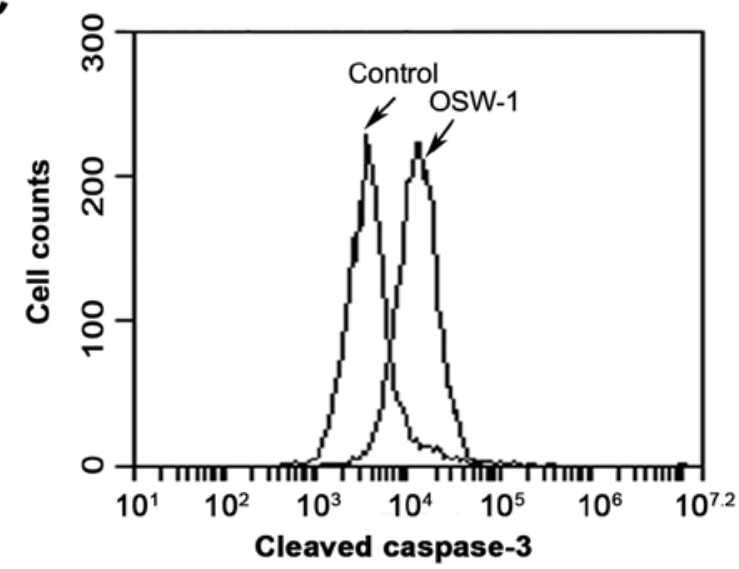

B

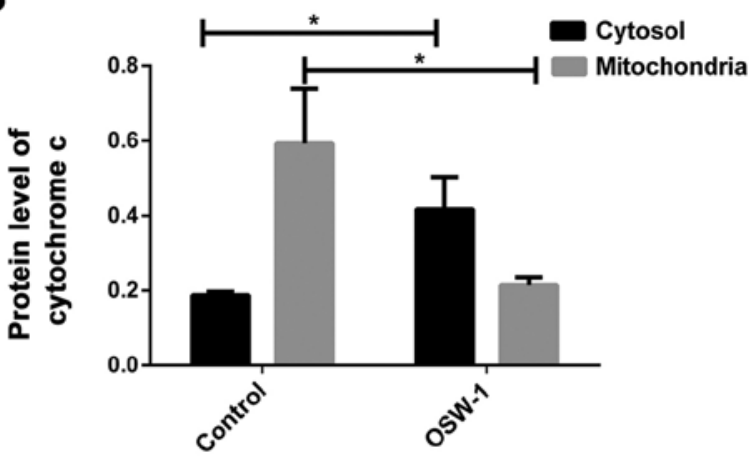

D

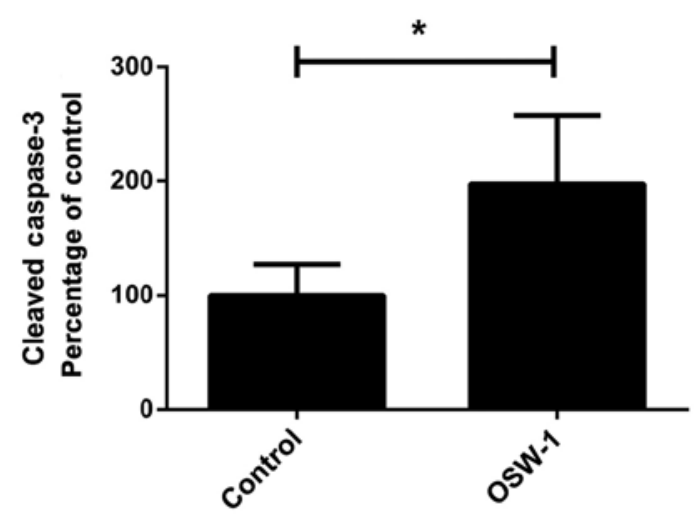

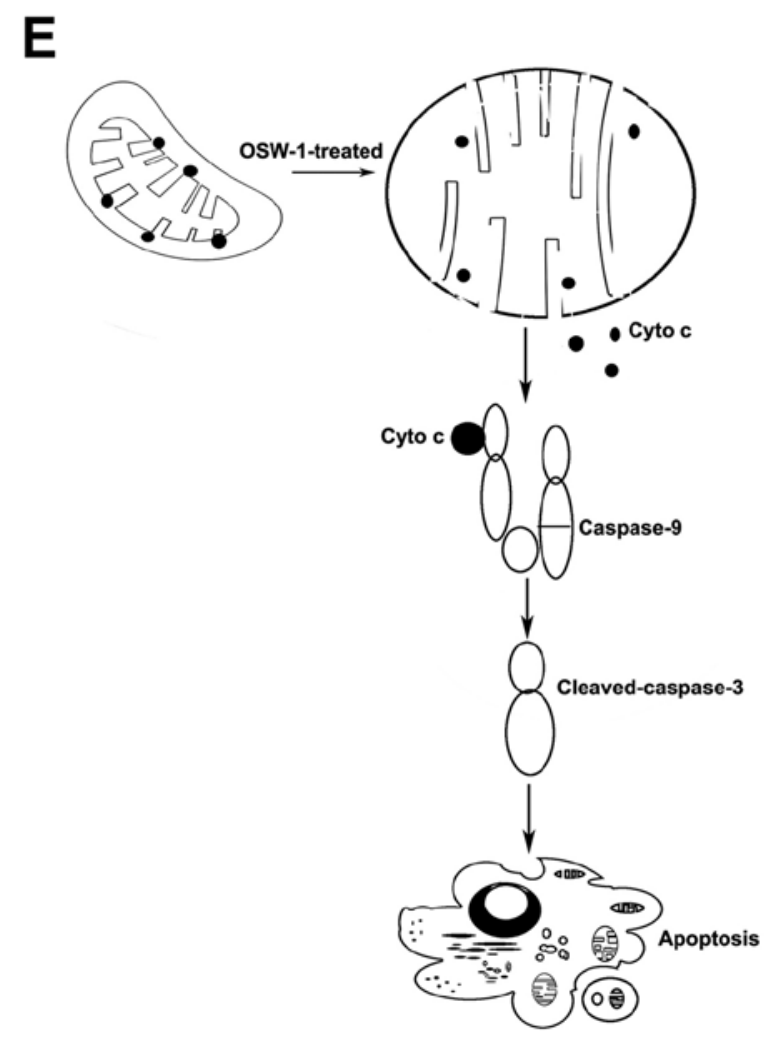

Figure 4. OSW-1-induced cell apoptosis is mediated by mitochondrial pathway. (A) After LoVo cells were treated with 180 ng/ml OSW-1 for 8 h, mitochondria and cytoplasm were isolated with mitochondria extraction kit. Cytochrome c in mitochondria and cytoplasm of two groups were detected by western blotting. (B) Quantitative analysis of cytochrome c expression in mitochondria and cytoplasm by western blotting. (C) The cleaved caspase-3 in cytoplasm of two groups was detected by flow cytometry fluorescence analysis. (D) Quantitative analysis of cleaved caspase-3 in the cytoplasm by flow cytometry fluorescence analysis. (E) The anticancer effect of OSW-1 is proposed to be activated by mitochondrial-mediated signal pathway of apoptosis. OSW-1 changed mitochondrial membrane potential and disrupted mitochondrial morphology, and finally caused release of cytochrome $\mathrm{c}$ and increased activation of caspase- 9 and -3 . ${ }^{*} \mathrm{P}<0.05$, compared with control. 
A

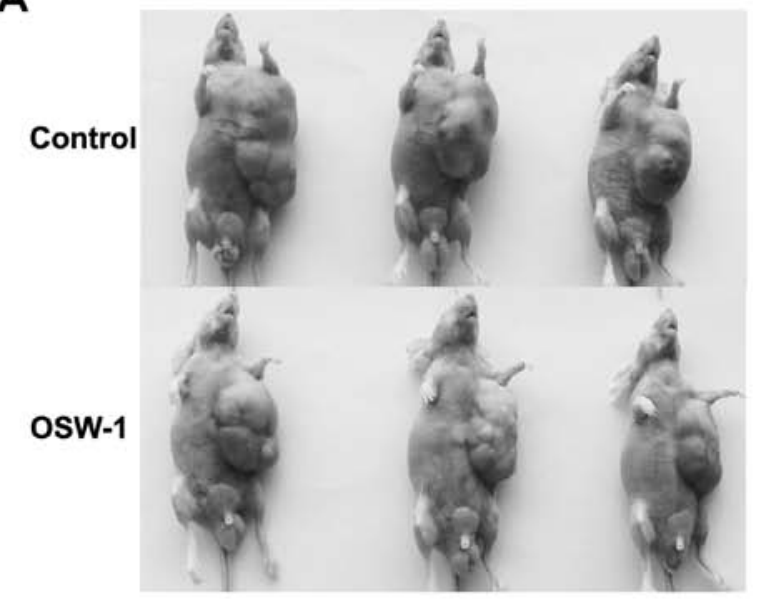

B

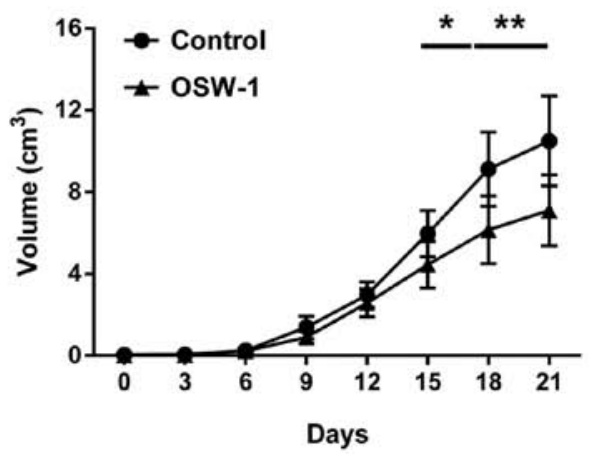

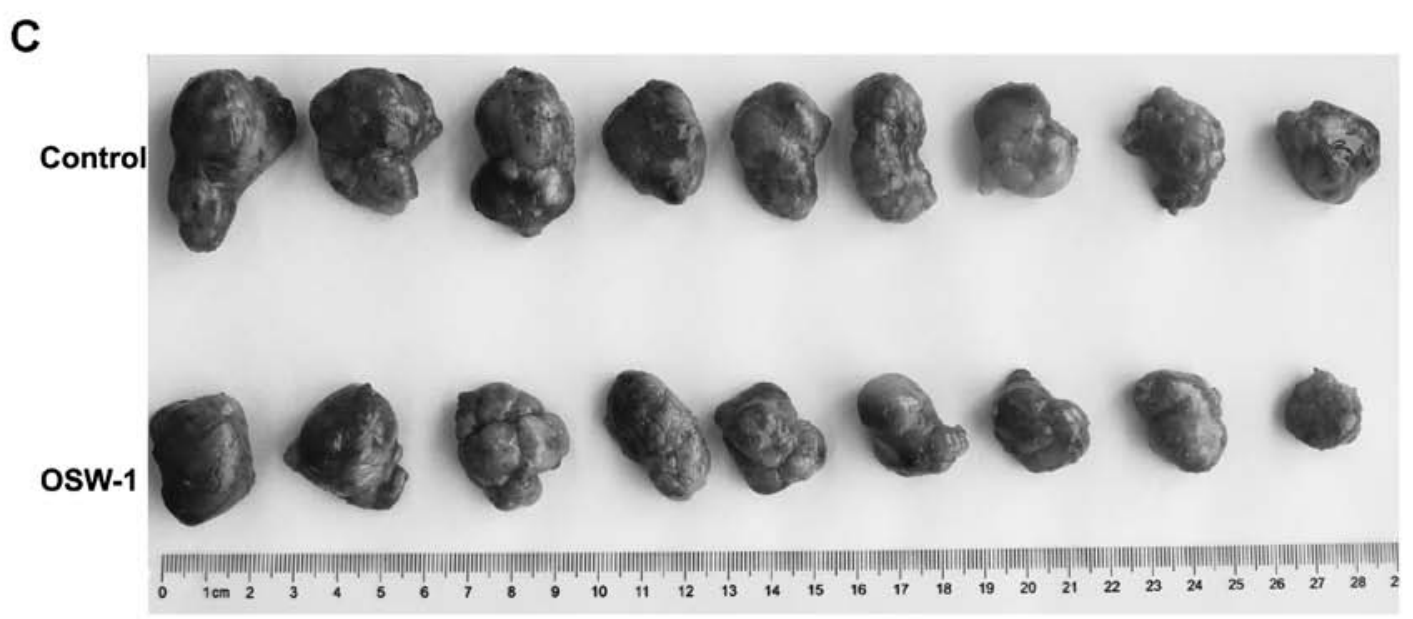

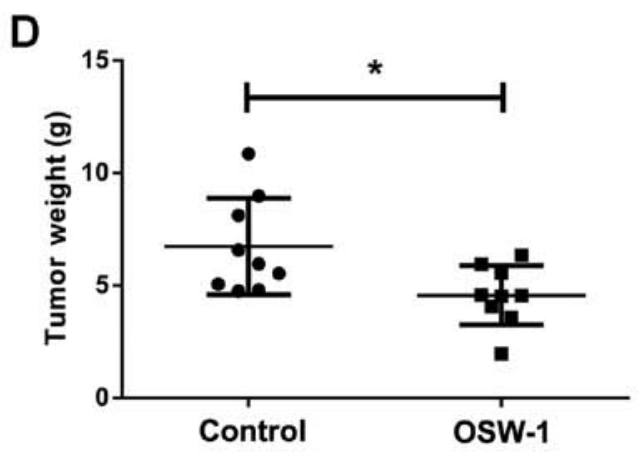

Figure 5. OSW-1 suppresses colon cancer in nude mice. (A) The representative xenografts of LoVo human colon cancer in nude mice. (B) Tumor growth curve of LoVo cells in nude mice of two groups. The data are mean values \pm SD (n=9/group). (C) Tumors were isolated from nude mice of two groups in 21 day. (D) The weights of tumors in two groups are shown by the scattergram. ${ }^{*} \mathrm{P}<0.05 ;{ }^{* * *} \mathrm{P}<0.01$, compared with control.

number of necrotic foci within the tumor tissues of control mice, but not in OSW-1 mice (Fig. 6A), suggesting that tumor growth speed may be greater in control mice than OSW-1treated mice. Ki67 IHC staining results further supported this speculation, as Ki67-positive cells were mainly found in control mice, but rarely in treated mice $(\mathrm{P}<0.05$; Fig. $6 \mathrm{~B})$. Furthermore, we used TUNEL staining to determine whether or not OSW-1 suppressed colon tumor proliferation through the apoptotic pathway in vivo. The results showed countless apoptotic cells in OSW-1-treated tumor tissues, but few apoptotic cells in the control group (Fig. 6C), suggesting that OSW-1 suppressed colon tumor proliferation through apoptosis in vivo.

\section{Discussion}

OSW-1 is a natural compound that has shown considerable anticancer activity in several kinds of cancer cells, including pancreatic cancer, ovarian cancer, leukemia, human hepatomas, and malignant brain tumors $(5,39)$. Herein we showed that OSW-1 can also inhibit colon cancer cells more powerfully than other drugs. Furthermore, OSW-1 had low toxicity 
A

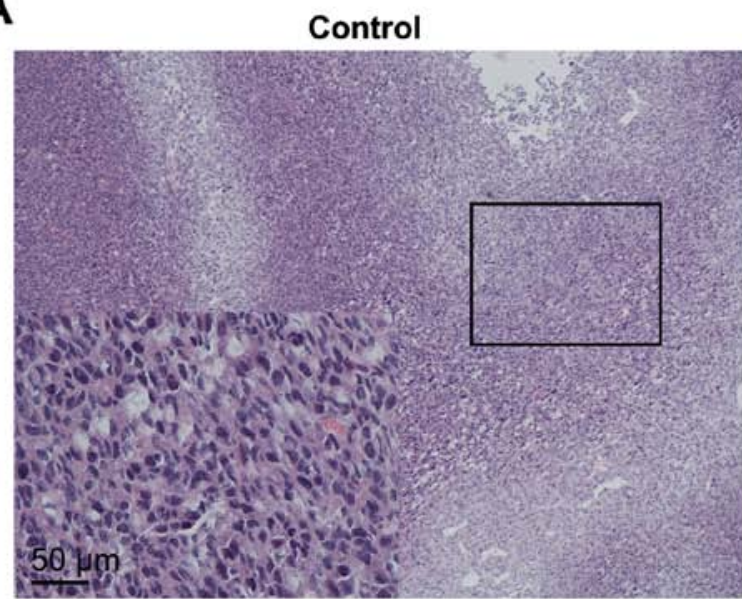

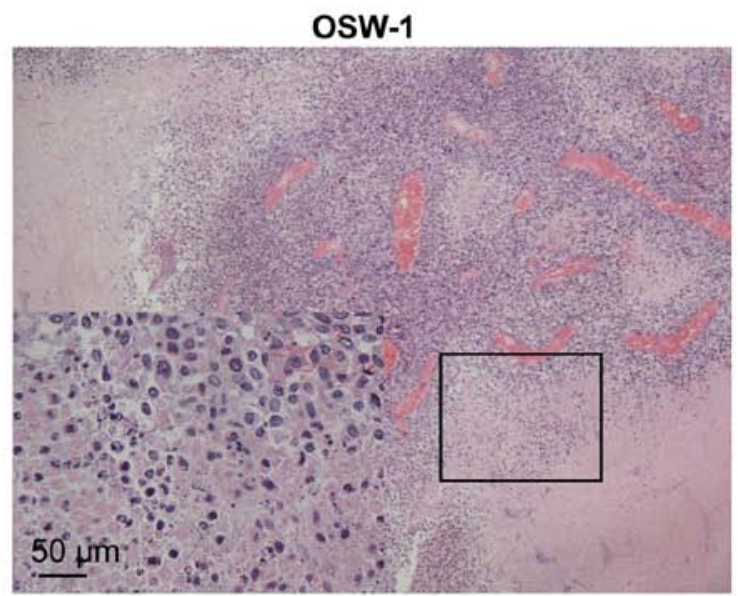

B
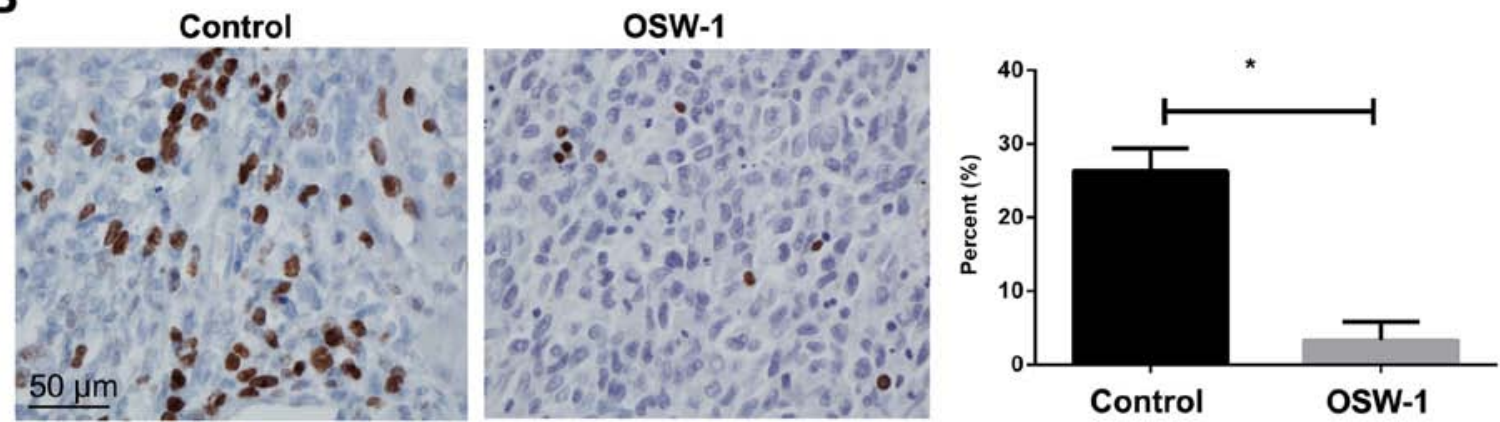

C

Control

OSW-1
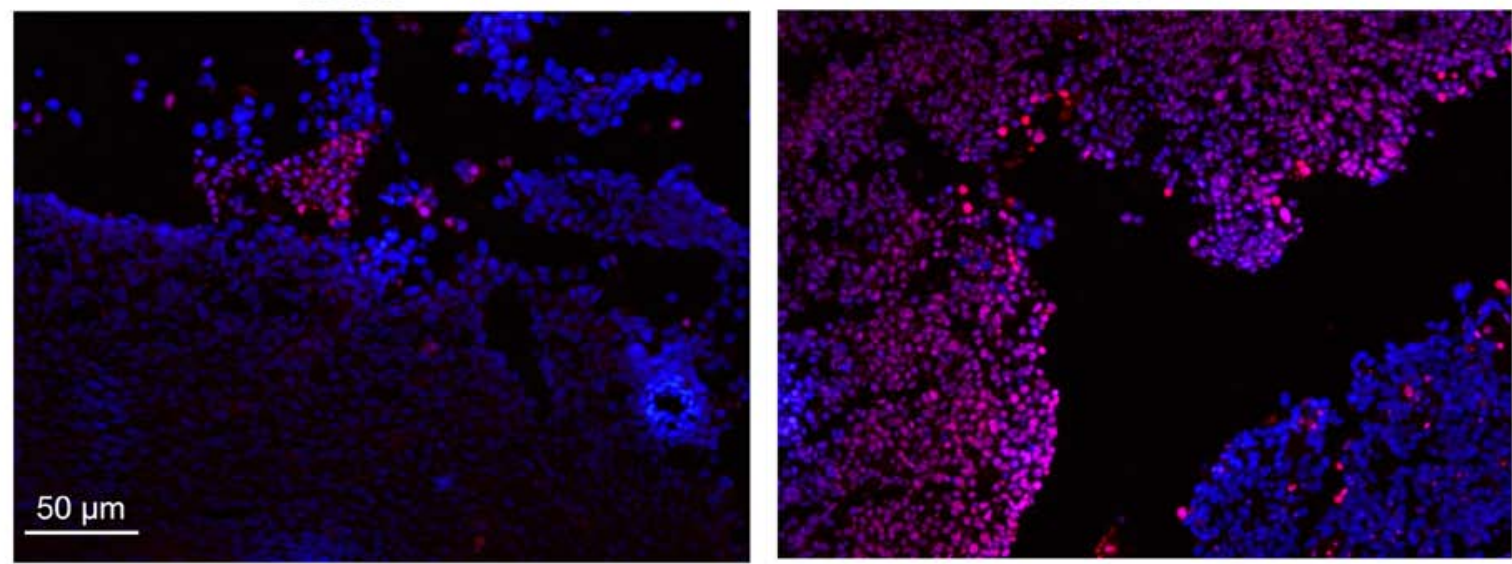

Figure 6. OSW-1 induced apoptosis of colon tumor cells in nude mice. (A) The haematoxylin and eosin staining of tumor tissue in two groups. (B) Ki67 immunohistochemical analysis of tumor tissue in two groups. The percents of Ki67 positive expression in two groups are shown in the bar graph. The data are mean values $\pm \mathrm{SD}$. (C) The TUNEL staining of tumor tissue in two groups. ${ }^{*} \mathrm{P}<0.05$, compared with control, Scale bar, $50 \mu \mathrm{m}$ in $(\mathrm{A}-\mathrm{C})$.

on human normal colonic mucosal epithelial cells in vitro. More importantly, OSW-1 is effective on colon cancer in vivo without significant side effects. Mimaki et al (28) even reported that OSW-1 can prolong the life span of mice bearing P388 leukemia cells, and this study is the second report regarding OSW-1-mediated colon tumor suppression in vivo. In addition, no signs of adverse drug reactions were observed during the entire course of OSW-1 treatment. Therefore, OSW-1 may be a new promising anticancer drug, which may be used to treat colon cancer in the future.

Apoptotic activity is essential for organ homeostasis by maintaining cell and tissue tropism in physiologic and pathologic circumstances $(40,41)$. Too much growth and too little death can lead to the disruption of homeostasis that may result in cancer (42). Previous studies have suggested that apoptosis, a universal cellular process, is the mechanism of many anticancer drugs (43-46). Several studies have reported that OSW-1 can induce calcium-dependent apoptosis by damaging the mitochondrial membrane and disrupting cellular homeostasis or caspase-8-dependent cleavage of Bcl-2 in leukemia and Chinese hamster ovary (CHO) cells in vitro, respectively $(34,35)$. We believe that apoptosis is a dominant pattern in the OSW-1-treated group based on the Annexin V assay, which was verified by the TUNEL assay in vitro. 
As apoptosis is divided into two main pathways (the extrinsic apoptotic pathway, which activates death receptors, and the intrinsic apoptotic pathway, which is mediated through the mitochondria) $(47,48)$. We used transmission electron microscopy to detect cellular artifacts and ascertain the mechanism of OSW-1-based apoptosis. We detected signs of mitochondria swelling and cristae fragmentation in mitochondrial morphology. Further evidence exhibits the loss of mitochondrial membrane potential though the treatment of OSW-1. These findings have highlighted that OSW-1 results in mitochondrial damage, both in morphology and function, and the basic biological question is which factors cause these changes. Bianchi et al (36) reported that mitochondria maintain a proper level of intracellular free calcium. Other studies have shown that $\mathrm{Ca}^{2+}$ is a critical sensitizing signal in the proapoptotic transition of mitochondria, which plays a key role in the regulation of cell death $(49,50)$.

To characterize the changes in calcium ion concentration, we detected the intracellular concentration of calcium ions by flow cytometry analysis using calcium indicators. We showed that OSW-1 caused an increase in cytosolic calcium. Interestingly, the increase was visible as early as $2 \mathrm{~h}$ and caused a time-dependent increase in cytosolic $\mathrm{Ca}^{2+}$ after the treatment with OSW-1, but this growing trend stopped and decreased at $10 \mathrm{~h}$ (data not shown). Furthermore, a large number of cells died $10 \mathrm{~h}$ after treatment with OSW-1. This finding provided evidence that $\mathrm{Ca}^{2+}$ took part in the cell death process. These findings suggest that OSW-1 can destroy mitochondria, which might lead to the destruction of calcium homeostasis and further caused rupture of the mitochondrial outer membrane. $\mathrm{Ca}^{2+}$ overload changed mitochondrial membrane potential and disrupted mitochondrial morphology. Next, we further characterized the pathway of inducing apoptosis by OSW-1. Our study showed that cytochrome $\mathrm{c}$ was released from mitochondria to the cytoplasm which appeared to cause caspase-3 activation, which was recognized as the mitochondrial apoptotic pathway (51-53). Therefore, these results indicated that OSW-1 inhibited LoVo cells through the intrinsic apoptotic pathway, and was involved in the process of OSW-1 suppression of LoVo cells in vivo based on TUNEL staining.

In this study, although apoptosis was shown to be the probable cause of cell death in LoVo cell lines treated with $90 \mathrm{ng} / \mathrm{ml}$ of OSW-1, if the cells were treated with $180 \mathrm{ng} / \mathrm{ml}$ of OSW-1, nearly $50 \%$ of necrotic cells were detected by flow cytometry. Therefore, with respect to high-dose OSW-1 treatment, other cell death pathways are implicated. In addition, we found destruction of blood vessels and a reduction in angiogenesis pathologically in OSW-1 treated mice (data not shown), and therefore speculate that OSW-1 inhibits the formation of new blood vessels and decreases the incidence of metastases. We did not find the presence of metastases that may be due to the short duration of the experiment ( $<30$ days). All of these questions need to be studied further.

In conclusion, we have identified OSW-1 as a natural compound with anti-neoplastic effect in vitro and in vivo via the intrinsic apoptotic pathway, although OWS-1 might also induce necrotic pathways in higher doses. The precise and unambiguous mechanism of the drug therefore requires further exploration. On the basis of these results alone, however, it is tempting to explore whether or not OSW-1 has equally valid anticancer activity on other cancers, and is an attractive candidate to be considered for patients in a clinical setting.

\section{Acknowledgements}

This study was supported by the Natural Science Foundation of Liaoning Province, China (grant no. 2014023028).

\section{References}

1. Torre LA, Bray F, Siegel RL, Ferlay J, Lortet-Tieulent J and Jemal A: Global cancer statistics, 2012. CA Cancer J Clin 65: 87-108, 2015.

2. Wani MC, Taylor HL, Wall ME, Coggon P and McPhail AT: Plant antitumor agents. VI. The isolation and structure of taxol, a novel antileukemic and antitumor agent from Taxus brevifolia. J Am Chem Soc 93: 2325-2327, 1971.

3. Kubo S, Mimaki Y, Terao M, Sashida Y, Nikaido T and Ohmoto T: Acylated cholestane glycosides from the bulbs of Ornithogalum saundersiae. Phytochemistry 31: 3969-3973, 1992.

4. Tang Y, Li N, Duan JA and Tao W: Structure, bioactivity, and chemical synthesis of OSW-1 and other steroidal glycosides in the genus Ornithogalum. Chem Rev 113: 5480-5514, 2013.

5. Zhou Y, Garcia-Prieto C, Carney DA, Xu RH, Pelicano H, Kang Y, Yu W, Lou C, Kondo S, Liu J, et al: OSW-1: A natural compound with potent anticancer activity and a novel mechanism of action. J Natl Cancer Inst 97: 1781-1785, 2005.

6. Jin J, Jin X, Qian C, Ruan Y and Jiang H: Signaling network of OSW-1-induced apoptosis and necroptosis in hepatocellular carcinoma. Mol Med Rep 7: 1646-1650, 2013.

7. Deng S, Yu B, Lou Y and Hui Y: First Total Synthesis of an Exceptionally Potent Antitumor Saponin, OSW-1. J Org Chem 64: 202-208, 1999.

8. Ma X, Yu B, Hui Y, Xiao D and Ding J: Synthesis of glycosides bearing the disaccharide of OSW-1 or its 1-->4-linked analogue and their antitumor activities. Carbohydr Res 329: 495-505, 2000.

9. Yu W and Jin Z: A new strategy for the stereoselective introduction of steroid side chain via alpha-alkoxy vinyl cuprates: Total synthesis of a highly potent antitumor natural product OSW-1. J Am Chem Soc 123: 3369-3370, 2001.

10. Ma X, Yu B, Hui Y, Miao Z and Ding J: Synthesis of steroidal glycosides bearing the disaccharide moiety of OSW-1 and their antitumor activities. Carbohydr Res 334: 159-164, 2001.

11. Ma X, Yu B, Hui Y, Miao Z and Ding J: Synthesis of OSW-1 analogues and a dimer and their antitumor activities. Bioorg Med Chem Lett 11: 2153-2156, 2001.

12. Morzycki JW and Wojtkielewicz A: Synthesis of a cholestane glycoside OSW-1 with potent cytostatic activity. Carbohydr Res 337: 1269-1274, 2002.

13. Yu W and Jin Z: Total synthesis of the anticancer natural product OSW-1. J Am Chem Soc 124: 6576-6583, 2002.

14. Deng L, Wu H, Yu B, Jiang M and Wu J: Synthesis of OSW-1 analogs with modified side chains and their antitumor activities. Bioorg Med Chem Lett 14: 2781-2785, 2004.

15. Morzycki JW, Wojtkielewicz A and Wołczyński S: Synthesis of analogues of a potent antitumor saponin OSW-1. Bioorg Med Chem Lett 14: 3323-3326, 2004.

16. Peng W, Tang P, Hu X, Liu JO and Yu B: Synthesis of the A,B-ring-truncated OSW saponin analogs and their antitumor activities. Bioorg Med Chem Lett 17: 5506-5509, 2007.

17. Tang P, Mamdani F, Hu X, Liu JO and Yu B: Synthesis of OSW saponin analogs with modified sugar residues and their antiproliferative activities. Bioorg Med Chem Lett 17: 1003-1007, 2007.

18. Xue J, Liu P, Pan Y and Guo Z: A total synthesis of OSW-1. J Org Chem 73: 157-161, 2008.

19. Kang Y, Lou C, Ahmed KB, Huang P and Jin Z: Synthesis of biotinylated OSW-1. Bioorg Med Chem Lett 19: 5166-5168, 2009.

20. Zheng D, Guan Y, Chen X, Xu Y, Chen X and Lei P: Synthesis of cholestane saponins as mimics of OSW-1 and their cytotoxic activities. Bioorg Med Chem Lett 21: 3257-3260, 2011.

21. Guan Y, Zheng D, Zhou L, Wang H, Yan Z, Wang N, Chang H, She P and Lei P: Synthesis of 5(6)-dihydro-OSW-1 analogs bearing three kinds of disaccharides linking at 15-hydroxy and their antitumor activities. Bioorg Med Chem Lett 21: 2921-2924, 2011.

22. Maj J, Morzycki JW, Rárová L, Oklest'ková J, Strnad M and Wojtkielewicz A: Synthesis and biological activity of 22-deoxo23-oxa analogues of saponin OSW-1. J Med Chem 54: 3298-3305, 2011. 
23. Sakurai K, Takeshita T, Hiraizumi M and Yamada R: Synthesis of OSW-1 derivatives by site-selective acylation and their biological evaluation. Org Lett 16: 6318-6321, 2014.

24. Guan YY, Song C and Lei PS: Synthesis of three OSW-1 analogs with maltose side chains bearing different protection groups. J Asian Nat Prod Res 16: 43-52, 2014.

25. Zongxu Han: The preparation method of compound Wannianqing capsules. Chinese patent CN 1,352,986. Filed June 12, 2002.

26. Zongxu Han: The preparation method of anti-liver-cancer drug. Chinese patent. CN 1,354,011. Filed June 19, 2002.

27. Xinbo LV and Zongxu Han: The preparation method of Ornithogalum saundersiae extract and its application. Chinese patent. CN 1,672,728. Filed September 28, 2005.

28. Mimaki Y, Kuroda M, Kameyama A, Sashida Y, Hirano T, Oka K, Maekawa R, Wada T, Sugita K and Beutler JA: Cholestane glycosides with potent cytostatic activities on various tumor cells from Ornithogalum saundersiae Bulbs. Bioorg Med Chem Lett 7: 633-636, 1997.

29. Melstrom LG, Bentrem DJ, Salabat MR, Kennedy TJ, Ding XZ, Strouch M, Rao SM, Witt RC, Ternent CA, Talamonti MS, et al: Overexpression of 5-lipoxygenase in colon polyps and cancer and the effect of 5-LOX inhibitors in vitro and in a murine model. Clin Cancer Res 14: 6525-6530, 2008.

30. Hewitt RE, McMarlin A, Kleiner D, Wersto R, Martin P, Tsokos M, Stamp GW and Stetler-Stevenson WG: Validation of a model of colon cancer progression. J Pathol 192: 446-454, 2000

31. Drewinko B, Romsdahl MM, Yang LY, Ahearn MJ and Trujillo JM: Establishment of a human carcinoembryonic antigen-producing colon adenocarcinoma cell line. Cancer Res 36: 467-475, 1976.

32. Jing L, He MT, Chang Y, Mehta SL, He QP, Zhang JZ and Li PA Coenzyme Q10 protects astrocytes from ROS-induced damage through inhibition of mitochondria-mediated cell death pathway. Int J Biol Sci 11: 59-66, 2015.

33. Beauregard AP, Harquail J, Lassalle-Claux G, Belbraouet M, Jean-Francois J, Touaibia M and Robichaud GA: CAPE analogs induce growth arrest and apoptosis in breast cancer cells. Molecules 20: 12576-12589, 2015.

34. Garcia-Prieto C, Riaz Ahmed KB, Chen Z, Zhou Y, Hammoudi N, Kang Y, Lou C, Mei Y, Jin Z and Huang P: Effective killing of leukemia cells by the natural product OSW-1 through disruption of cellular calcium homeostasis. J Biol Chem 288: 3240-3250, 2013.

35. Zhu J, Xiong L, Yu B and Wu J: Apoptosis induced by a new member of saponin family is mediated through caspase-8dependent cleavage of Bcl-2. Mol Pharmacol 68: 1831-1838, 2005.

36. Bianchi K, Rimessi A, Prandini A, Szabadkai G and Rizzuto R Calcium and mitochondria: Mechanisms and functions of a troubled relationship. Biochim Biophys Acta 1742: 119-131, 2004
37. Zimmermann KC, Bonzon $\mathrm{C}$ and Green DR: The machinery of programmed cell death. Pharmacol Ther 92: 57-70, 2001.

38. Oberst A, Bender C and Green DR: Living with death: The evolution of the mitochondrial pathway of apoptosis in animals. Cell Death Differ 15: 1139-1146, 2008.

39. Jin JC, Jin XL, Zhang X, Piao YS and Liu SP: Effect of OSW-1 on microRNA expression profiles of hepatoma cells and functions of novel microRNAs. Mol Med Rep 7: 1831-1837, 2013.

40. Nagata S: Apoptosis by death factor. Cell 88: 355-365, 1997.

41. Ellis RE, Yuan JY and Horvitz HR: Mechanisms and functions of cell death. Annu Rev Cell Biol 7: 663-698, 1991.

42. Igney FH and Krammer PH: Death and anti-death: Tumour resistance to apoptosis. Nat Rev Cancer 2: 277-288, 2002.

43. Shen L, Li J, Xu L, Ma J, Li H, Xiao X, Zhao J and Fang L: miR-497 induces apoptosis of breast cancer cells by targeting Bcl-w. Exp Ther Med 3: 475-480, 2012.

44. Kim SH and Choi KC: Anti-cancer effect and underlying mechanism(s) of kaempferol, a phytoestrogen, on the regulation of apoptosis in diverse cancer cell models. Toxicol Res 29: 229-234, 2013.

45. Kasiri S, Ansari KI, Hussain I, Bhan A and Mandal SS: Antisense oligonucleotide mediated knockdown of HOXC13 affects cell growth and induces apoptosis in tumor cells and over expression of HOXC13 induces 3D-colony formation. RSC Advances 3: 3260-3269, 2013.

46. Ponci V, Figueiredo CR, Massaoka MH, de Farias CF, Matsuo AL, Sartorelli P and Lago JH: Neolignans from Nectandra megapotamica (Lauraceae) display in vitro cytotoxic activity and induce apoptosis in leukemia cells. Molecules 20: 12757-12768, 2015.

47. Green DR: Apoptotic pathways: Paper wraps stone blunts scissors. Cell 102: 1-4, 2000.

48. Fulda S and Debatin KM: Extrinsic versus intrinsic apoptosis pathways in anticancer chemotherapy. Oncogene 25: 4798-4811, 2006.

49. Kroemer G and Reed JC: Mitochondrial control of cell death. Nat Med 6: 513-519, 2000.

50. Mattson MP and Chan SL: Calcium orchestrates apoptosis. Nat Cell Biol 5: 1041-1043, 2003.

51. Zamzami N and Kroemer G: The mitochondrion in apoptosis: How Pandora's box opens. Nat Rev Mol Cell Biol 2: 67-71, 2001.

52. Martinou JC and Green DR: Breaking the mitochondrial barrier. Nat Rev Mol Cell Biol 2: 63-67, 2001.

53. Kulikov AV, Shilov ES, Mufazalov IA, Gogvadze V, Nedospasov SA and Zhivotovsky B: Cytochrome c: The Achilles' heel in apoptosis. Cell Mol Life Sci 69: 1787-1797, 2012. 